\title{
A missing tooth after intubation
}

\author{
Anita Tammara, ${ }^{1}$ Robert Michael Reed, ${ }^{2}$ Avelino C Verceles ${ }^{2}$
}

${ }^{1}$ School of Medicine, University of Maryland, Baltimore, Maryland, USA

${ }^{2}$ Division of Pulmonary and Critical Care Medicine, University of Maryland, Baltimore, Maryland, USA

\section{Correspondence to} Dr Robert Michael Reed, rreed@medicine.umaryland.edu

Accepted 2 November 2014

CrossMark

To cite: Tammara $A$ Reed RM, Verceles AC. BMJ Case Rep Published online: [please include Day Month Yearl doi:10.1136/bcr-2014 207145

\section{DESCRIPTION}

A middle-aged man developed hypoxemic respiratory failure requiring emergent endotracheal intubation for airway management. Postintubation chest X-ray revealed a foreign body located in the trachea (figure 1), which was later determined to be a dislodged tooth. Dental injuries during endotracheal intubation are estimated to occur on average 1.13\% of the time, with an incidence ranging as high as $12.1 \%$ when patients have loose teeth. ${ }^{1}$ Aspiration of foreign bodies such as teeth or food particles can lead to airway obstruction, aspiration pneumonitis and lung collapse. In the context of preoperative management for elective surgeries, evidence supports a proper oral examination to prevent foreign body aspiration. ${ }^{2}$ Loose teeth, crowns or dental caries that can be addressed prior to surgery can decrease the number of perioperative dental complications. When emergent intubation results in tooth aspiration, the maxillary incisors (the left in particu-

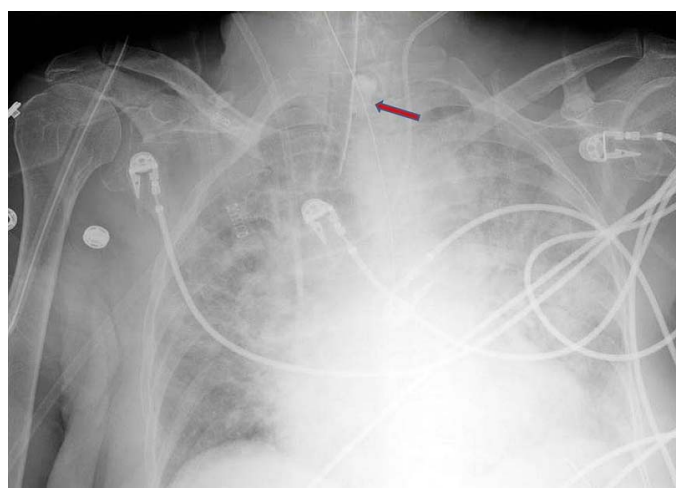

Figure 1 Anterioposterior view-chest X-ray revealing tooth lodged above the cuff of the endotracheal tube (red arrow). lar) are most commonly involved due to the preferential left-sided manipulation of the endotracheal tube and stylet during airway management. Proper technique is important to prevent dislodging loose teeth during endotracheal intubation. ${ }^{3}$ Current evidence demonstrates that direct visualisation using a videolaryngoscope, (ie, Glidescope) reduces rates of dental complications by 10 -fold when compared to traditional direct laryngoscopy technique.

\section{Learning points}

Foreign body aspiration and associated complications may occur during endotracheal intubation.

- Proper dental examination is important in preventing tooth aspiration preoperatively.

- Using a video laryngoscope method for intubation results in fewer dental complications.

\section{Competing interests None.}

Patient consent None.

Provenance and peer review Not commissioned; externally pee reviewed.

\section{REFERENCES}

1 Vogel J, Stubinger S, Kaufmann M, et al. Dental injuries resulting from tracheal intubation - a retrospective study. Dent Traumatol 2009;25:73-7.

2 Chadwick RG, Lindsay SM. Dental injuries during general anaesthesia: can the dentist help the anaesthetist? Dent Update 1998:25:76-8

3 Rabiner JE, Auerbach M, Avner JR, et al. Comparison of GlideScope Videolaryngoscopy to Direct Laryngoscopy for Intubation of a Pediatric Simulator by Novice Physicians. Emerg Med Int 2013:2013:407547

Copyright 2014 BMJ Publishing Group. All rights reserved. For permission to reuse any of this content visit http://group.bmj.com/group/rights-licensing/permissions.

BMJ Case Report Fellows may re-use this article for personal use and teaching without any further permission.

Become a Fellow of BMJ Case Reports today and you can:

- Submit as many cases as you like

- Enjoy fast sympathetic peer review and rapid publication of accepted articles

- Access all the published articles

- Re-use any of the published material for personal use and teaching without further permission

For information on Institutional Fellowships contact consortiasales@bmjgroup.com

Visit casereports.bmj.com for more articles like this and to become a Fellow 